Please do not remove this page

RMIT

UNIVERSITY

\title{
Academic staff development as a catalyst for curriculum change towards education for sustainable development: an output perspective
}

Barth, Matthias; Rieckmann, Marco

https://researchrepository.rmit.edu.au/esploro/outputs/9921858666201341/filesAndLinks?institution=61RMIT_INST\&index=null

Barth, M., \& Rieckmann, M. (2012). Academic staff development as a catalyst for curriculum change towards education for sustainable development: an output perspective. Journal of Cleaner Production, 26, 28-36. https://doi.org/10.1016/j.jclepro.2011.12.011

Document Version: Accepted Manuscript

Published Version: https://doi.org/10.1016/j.jclepro.2011.12.011

Repository homepage: https://researchrepository.rmit.edu.au

(c) 2011 Elsevier Ltd. All rights reserved.

Downloaded On 2023/04/27 00:20:55 +1000 
Thank you for downloading this document from the RMIT Research Repository.

The RMIT Research Repository is an open access database showcasing the research outputs of RMIT University researchers.

RMIT Research Repository: http://researchbank.rmit.edu.au/

\section{Citation:}

Barth, M and Rieckmann, M 2012, 'Academic staff development as a catalyst for curriculum change towards education for sustainable development: an output perspective', Journal of Cleaner Production, vol. 26, pp. 28-36.

See this record in the RMIT Research Repository at:

http://researchbank.rmit.edu.au/view/rmit:16170

Version: Accepted Manuscript

Copyright Statement: (c) 2011 Elsevier Ltd. All rights reserved.

Link to Published Version:

http://dx.doi.org/10.1016/j.jclepro.2011.12.011

\section{PLEASE DO NOT REMOVE THIS PAGE}


Matthias Barth, Marco Rieckmann

\section{Academic staff development as a catalyst for curriculum change towards education for sustainable development: an output perspective}

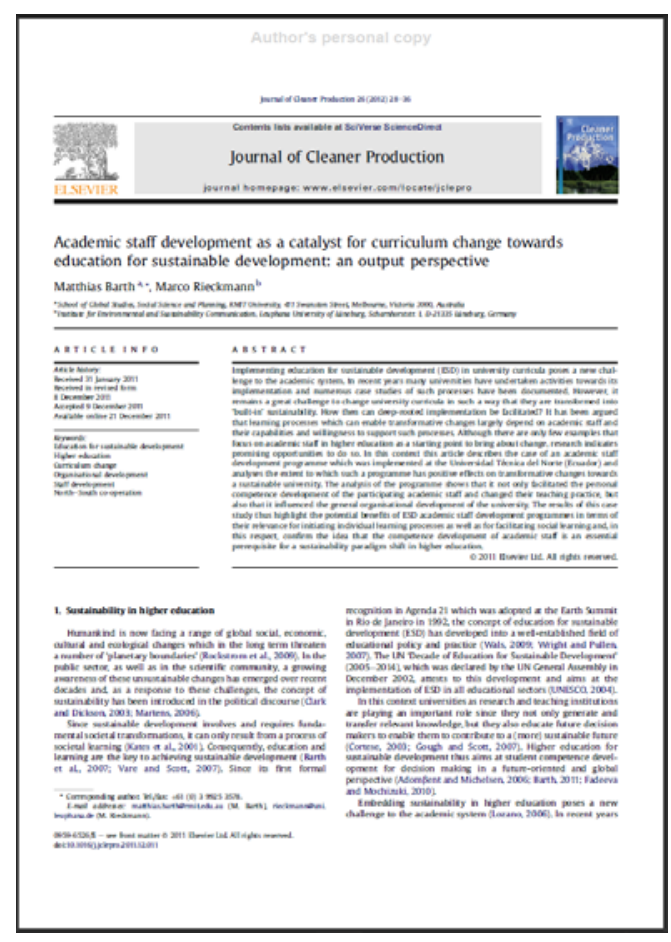

Published in the Journal of Cleaner Production

Available at:

http://www.sciencedirect.com/science/article/ pii/S0959652611005361

\section{Citation:}

Barth, M., \& Rieckmann, M. (2012). Academic staff development as a catalyst for curriculum change towards education for sustainable development: an output perspective. Journal of Cleaner Production, 26(1), 28-36. DOI: 10.1016/j.jclepro.2011.12.011

\section{Version:}

Authors' final postprint version

Online since:

22nd of December 2012 


\title{
Academic staff development as a catalyst for curriculum change towards education for sustainable development: an output perspective
}

\begin{abstract}
Implementing education for sustainable development (ESD) in university curricula poses a new challenge to the academic system. In recent years many universities have undertaken activities towards its implementation and numerous case studies of such processes have been documented. However, it remains a great challenge to change university curricula in such a way that they are transformed into 'built-in' sustainability. How then can deep-rooted implementation be facilitated? It has been argued that learning processes which can enable transformative changes largely depend on academic staff and their capabilities and willingness to support such processes. Although there are only few examples that focus on academic staff in higher education as a starting point to bring about change, research indicates promising opportunities to do so. In this context this article describes the case of an academic staff development programme which was implemented at the Universidad Técnica del Norte (Ecuador) and analyses the extent to which such a programme has positive effects on transformative changes towards a sustainable university. The analysis of the programme shows that it not only facilitated the personal competence development of the participating academic staff and changed their teaching practice, but also that it influenced the general organisational development of the university. The results of this case study thus highlight the potential benefits of ESD academic staff development programmes in terms of their relevance for initiating individual learning processes as well as for facilitating social learning and, in this respect, confirm the idea that the competence development of academic staff is an essential prerequisite for a sustainability paradigm shift in higher education.
\end{abstract}

\section{Keywords}

- Education for sustainable development;

- Higher education;

- Curriculum change;

- Organisational development;

- Staff development;

- North-South co-operation 


\section{Sustainability in higher education}

Humankind is now facing a range of global social, economic, cultural and ecological changes which in the long term threaten a number of 'planetary boundaries' (Rockstrom et al., 2009). In the public sector, as well as in the scientific community, a growing awareness of these unsustainable changes has emerged over recent decades and, as a response to these challenges, the concept of sustainability has been introduced in the political discourse (Clark and Dickson, 2003; Martens, 2006).

Since sustainable development involves and requires fundamental societal transformations, it can only result from a process of societal learning (Kates et al., 2001). Consequently, education and learning are the key to achieving sustainable development (Barth et al., 2007; Vare and Scott, 2007). Since its first formal recognition in Agenda 21 which was adopted at the Earth Summit in Rio de Janeiro in 1992, the concept of education for sustainable development (ESD) has developed into a well-established field of educational policy and practice (Wals, 2009; Wright and Pullen, 2007). The UN 'Decade of Education for Sustainable Development' (2005-2014), which was declared by the UN General Assembly in December 2002, attests to this development and aims at the implementation of ESD in all educational sectors (UNESCO, 2004).

In this context universities as research and teaching institutions are playing an important role since they not only generate and transfer relevant knowledge, but they also educate future decision makers to enable them to contribute to a (more) sustainable future (Cortese, 2003; Gough and Scott, 2007). Higher education for sustainable development thus aims at student competence development for decision making in a future-oriented and global perspective (Adomßent and Michelsen, 2006; Barth 2011; Fadeeva and Mochizuki, 2010).

Embedding sustainability in higher education poses a new challenge to the academic system (Lozano 2006). In recent years many universities have undertaken activities towards its implementation, and numerous case studies, as well as studies on the drivers and barriers of such processes, have been documented (see, for example, Ferrer-Balas et al., 2009; Lidgren et al., 2006; Lozano, 2006; Lozano-Garcia et al., 2009; for an overview see, for instance, Thomas, 2004 or Leal Filho, 2009). However, it remains a great challenge to change curricula at universities in such a way that they are transformed into 'built-in' sustainability (Sterling and Thomas, 2006). A crucial question then is how its deep-rooted implementation can be facilitated.

In this article we focus on the role of academic staff and staff development programmes as one potential catalyst for such implementation. After considering both the state of the art in implementing sustainability in higher education and social learning as a driver of organisational change, a specific staff development programme is introduced and analysed as a case study. The findings on outputs of this programme on different levels are presented and critically discussed.

\section{Implementing sustainability in higher education}

Over the last few years numerous case studies have revealed a great variety of approaches to implementing ESD in higher education. First of all, a number of different initiatives and pilot projects involving sustainable development as an important issue in higher education have been launched. Disciplinary fields in the natural sciences as well as teacher education have taken up the general concept of sustainability, while at the same time 
new courses and course specialisations have been developed in which sustainable development is the exclusive subject matter (e.g. Juárez-Nájera et al., 2006 and Vann et al., 2006; see also Flint et al., 2000, and Perdan et al., 2000). The 'storytelling' approach of such case studies is criticised by Corcoran et al. (2004, p. 8), arguing that 'such case-study research would be more effective in bringing about change if it were better theorized and documented.' Similarly, Fien (2002, p. 144) states: 'Few studies have thought to go beyond description to include a critical and theoretical analysis of findings or to ground explanations in social or organisational theory.'

More recent case studies focus on how ESD approaches introduce a more general pedagogical innovation (Bremer and López-Franco, 2006; Epstein et al., 2009; Hoare et al., 2008), how they affect curriculum development (McMillin and Dyball, 2009; Murray and Murray, 2007), and finally, the existence of specific drivers and barriers (Jones et al., 2008; Lozano, 2006; Uwasu et al., 2009). The challenges and opportunities of such processes are also investigated in meta-analyses which cluster different approaches according to their empirical data (Gough and Scott, 2007; de la Harpe and Thomas, 2009; Thomas, 2004), and theoretically grounded concepts are developed focusing on the processes of implementation (Scott and Gough, 2006; Tilbury, 2004).

These areas of research are also linked with general curriculum change research. Here, literature offers three different but interlinked strands of research for consideration: (1) the examination of stages of curriculum change and conditions necessary for institutional adoption (Barnett et al., 2001; Drake, 1998; Fullan, 2003); (2) the internal and external influences that support or hinder implementation (Dressel and Marcus, 1982; Stark and Lattuca, 1997; Trinkaus and Booke, 1980); (3) obstacles to the academic innovation process (Ellsworth, 2000; Lindquist, 1974; Toombs and Tierney, 1991).

A number of frameworks distinguish different patterns of ESD implementation. Lozano (2010) has found four different approaches, ranging from limited coverage in an existing module, specific SD modules, and discipline-oriented modules with integrated SD topics to SD as an optional specialisation within a course of study. In a similar approach Barth and Timm (2011) emphasise the process character of implementation from introductory lecture series to transformative curriculum change. Similarly, Sterling and Thomas (2006) suggest that there are four levels and types of responses, from denial (no change) to 'bolt-on' approaches (education about sustainability), 'built-in' approaches (education for sustainability), and finally curriculum redesign (sustainable education). However, only a few higher education institutions have dared to tackle the challenge of such reorienting of a university's entire educational mission, a process for which learning is said to be crucial (Sterling, 2004).

\section{Social learning and the role of academic staff in organisational change}

Theory on organisational change widely acknowledges the importance of learning processes taking place both individually and collaboratively (e.g. Argyris, 2009; Argyris and Schön, 1996; Kotter, 1996; Senge, 2006) and explores different forms of learning and their respective results (Eckel and Kezar, 2003; Siebenhüner and Arnold, 2007). In order to facilitate a paradigm shift in the curriculum design proposed by Sterling and Thomas (2006), social learning is seen as a necessary prerequisite for sustainability learning (Hansmann, 2010). 
First of all, social learning refers to learning 'that takes place when divergent interests, norms, values and constructions of reality meet in an environment that is conducive to learning' (Wals and van der Leij, 2007, p. 18). Social learning both characterises and contributes to a 'learning system' in which people learn from and with each other and as a result become individually and collectively more competent. The differences in views, values and beliefs are not only accepted, but are also a key to the learning process. Social learning is increasingly being used by organisations and companies in order to actively involve people in change processes (Cramer and Loeber, 2007; Lund-Thomsen, 2007). Thus, according to Keen et al. (2005, p. 4), social learning may be understood as 'the collective action and reflection that occurs among different individuals and groups as they work to improve the management of human and environmental interrelations.'

Learning itself, however, is a neutral process that can keep a system stable or enable it to change (Sterling, 2007). Learning processes which utilise individual differences and depend on social interaction may also be described as transformative or second order learning. According to Ison and Russell, second order learning is 'change that is so fundamental that the system itself is changed. In order to achieve (this), it is necessary to step outside the usual frame of reference and take a meta-perspective' (Ison and Russell, 2000, p. 229). In contrast to 'default' first order learning, second order learning leads to questioning and reordering individual and collective assumptions.

It has been argued that learning processes which enable transformative changes largely depend on academic staff and their capabilities and willingness to support such processes (Hegarty, 2008). ESD in higher education not only requires innovation in teaching and learning, but also challenges the capabilities of academic staff and is a question of lifelong learning. '[...] teachers are at the centre of curricular development when directing it more towards sustainability, because they are responsible for the introduction of the subject of SD to their students' (Ceulemans and De Prins, 2010, p. 646). Although there are only few examples that have focused on academic staff in higher education as a starting point to bring about change, research indicates promising opportunities (Huisingh and Mebratu, 2000; Roberts and Roberts, 2008). Facilitating lifelong learning processes amongst academic staff can help to improve their learning and teaching capabilities and, even more importantly, can offer a meaningful reason for individual reflection on how ESD might be best implemented (Lozano-Garcia et al., 2008). Lozano (2006, p. 793) describes 'educating the educators' as an important element for promoting the incorporation of ESD into universities, because 'a clear understanding of SD is necessary for the incorporation of the concept' (cf. also Holmberg et al., 2008).

In this context this article describes the case of an academic staff development programme which has been implemented at an Ecuadorian university and analyses the extent to which this programme has positive effects on transformative changes towards a sustainable university. Based on the theoretical derived assumptions of the importance of social learning processes of the academic staff as a catalyst for organisational change, it is explored how such learning takes place, which consequences are involved, and to what extent it changes the organisation`s development.

\section{Context of the case study: a one-year academic staff development programme at the Universidad Técnica del Norte}

The research reported in this article draws upon a one-year academic staff 
development programme, 'Higher Education for Sustainable Development', which was implemented at the Universidad Técnica del Norte (UTN), Ecuador, in 2009. It was jointly developed within the international project 'Teaching and Learning Sustainability' undertaken by the UTN and the Leuphana University of Lüneburg, Germany and aims at broader implementation of sustainability in the curriculum of the UTN. Based on the premise that university teachers are key agents for change, the specific aim of the project is the integration of ESD in overall teaching practice. It targets academic staff to support the development of relevant capabilities to facilitate ESD.

The academic staff development programme has been designed and implemented as a formally accredited one-year programme ('especialización') with a total workload of 720 hours split into seven modules over two semesters. ${ }^{1}$ The programme's target are teachers of the UTN who are interested in sustainability but who so far have had little or no previous experience with either sustainability issues or ESD. The programme first intends to develop a basic understanding of ESD key principles and, subsequently, to apply such knowledge in real teaching situations. The first semester introduces a number of different topics and approaches related to ESD and teaching and learning in general, while the second semester is closely linked with the teaching and learning practice of the participants. Each participant develops at least one module either by designing a completely new module or by redesigning an existing module along ESD principles. The development, implementation and evaluation of these modules are accompanied by two workshops at the beginning and end of the second semester (see Table 1).

Table 1: Modules of the academic staff development programme

\begin{tabular}{|l|c|}
\hline Semester 1 & Workload \\
\hline Module & 96 \\
\hline Introduction to sustainable development (SD) & 96 \\
\hline Education for sustainable development (ESD) & 96 \\
\hline Methods of virtual learning in ESD & 144 \\
\hline Methods of ESD & 48 \\
\hline Information and Communication Technologies & $\mathbf{4 8 0}$ \\
\hline & \\
\hline Semester 2 & 120 \\
\hline First workshop: Development and implementation of ESD modules & 120 \\
\hline Second workshop: Evaluation of ESD modules & $\mathbf{2 4 0}$ \\
\hline
\end{tabular}

The programme is set out as a blended-learning course designed for self-directed, problem-oriented and collaborative learning. In the first semester the participants worked in five face-to-face seminars, each lasting two days. Between the seminars work was done in a moodle-based e-learning environment ${ }^{2}$ which offered a number of collaboration tools and served both as a platform for exchange among participants and as a means to receive support from the programme hosts. The ESD modules offered by the participating teachers in the second semester covered a wide variety of topics, such as industrial security, sustainable 
tourism, biodiversity, renewable energies, energy efficiency, education for sustainable development, climate change policy, textile production, sustainable management, nutrition, and sustainable agriculture. Most of the modules were designed as project seminars, and hence the students had to deal with real-life problems of unsustainability and had to find possible solutions. In some seminars the participants even applied a transdisciplinary approach by facilitating co-operation between their students and local communities or other stakeholders. The workshops at the beginning and end of the second semester focused on collaborative feedback and exchange on the design of the modules and the experiences of the participants.

In the first run 25 teachers from all of the faculties of the UTN expressed their interest and attended the first introductory session. Eighteen of them enrolled and successfully completed the programme. See Table 2 for more information on the socio-demographic data of the participants.

Table 2: Participants who successfully completed the programme

\begin{tabular}{|l|l|}
\hline Total number of participants & 18 \\
\hline Home country & Ecuador \\
\hline Disciplines & $\begin{array}{l}\text { educational sciences (1) } \\
\text { tourism (5) } \\
\text { business studies (2) } \\
\text { natural resources (1) } \\
\text { agronomy (2) } \\
\text { electrical engineering (3) } \\
\text { mechanical engineering (1) } \\
\text { textile studies (1) } \\
\text { health studies (2) }\end{array}$ \\
\hline Employment & $\begin{array}{l}\text { permanent (15), temporary (3) } \\
\text { full-time (15), part-time (3) }\end{array}$ \\
\hline Age & 32 -60 (average: 51) \\
\hline Gender & $\begin{array}{l}5 \text { female } \\
13 \text { male }\end{array}$ \\
\hline
\end{tabular}

The academic staff development programme was taught in Spanish and German (with simultaneous translation into Spanish). The main course material was an introductory text on sustainable development (Michelsen and Rieckmann, 2008), together with further readings available on the e-learning platform, including texts from both European and Latin-American authors, which ensured that the participants were exposed to a wide range of perspectives and prevented a unidirectional 'knowledge transfer' from the North to the South.

\section{Research focus and empirical design}

In the context of the implementation processes and the key role of academic staff described above this paper examines the impact of an academic staff development programme on the implementation process of ESD in higher education. Exploring the degree to which such a programme would support the general implementation process, and thus an organisational change towards sustainability, means considering at least three different outcomes: 
(1) Individual competencies of academic teaching staff members

The first and probably most obvious outcome is connected with the individual learning processes of all of the participants. The goal of academic staff development is to broaden understanding and increase knowledge about sustainability-related aspects; it also aims at reflection on, and discussion of, existing values, norms and assumptions. In this regard, it will be analysed which competencies, abilities and skills will be developed by the participating academic staff.

(2) Professional performance

Closely linked to the question of the individual competence development of academic teaching staff is the question of changing teaching routines. It is explored whether an academic staff development programme supports the integration of sustainability issues in the teaching routines of academic staff and leads to the development of new and innovative pedagogical approaches.

(3) Long-term organisational impact

Finally, and as a more indirect outcome, general organisational development is of interest. University teachers as key change agents not only educate future disseminators and multipliers of sustainability, but also function as active players able to shape the organisation they work in. Thus, it can be asked to what extent an academic staff development programme contributes to the dissemination of sustainability as a cross-cutting topic in the university where it is implemented.

The research reported in this article has been set out as an explorative case study to allow in-depth analysis of the impacts of an academic staff development programme on the implementation process of ESD in higher education. Case studies explore a 'bounded system' (Cresswell, 1998, p. 61) and offer opportunities to study the manifold factors that produced the unique character of the case. As a preferable strategy to answer 'how' and 'why' questions they allow contextual factors, and thus the singularity of a case, to be taken into account (Yin, 1989).

Different approaches of inquiry as well as different perspectives were used in order to study a number of aspects of the case, thus enabling a holistic analysis of the complexity of a real-world case (Bassey, 1999; Merriam, 1998). Data was collected using two main sources (see Table 3 for detailed information). To obtain information about the individual perception of the programme, its impact as well as collaborative aspects, three focus groups were conducted at the end of the first semester. By analysing focus groups, it is taken into consideration that subjective meaning structures are frequently integrated in social contexts which can only be surveyed in group situations (Denzin and Lincoln, 1998). The focus groups were realised using Morgan's (1997) process model, following a rough thematic guideline ('topic guide'). At the same time a document analysis of the participants' final module reports was conducted to gain a more detailed insight into the development of the modules and the relevance of the programme for the learning and teaching approaches of the participants.

Table 3: Overview of the data collection

\begin{tabular}{|l|l|l|l|}
\hline Method & $\begin{array}{l}\text { Data collection } \\
\text { period }\end{array}$ & Sample & Details \\
\hline Focus groups & February 2010 & 18 participants & $\begin{array}{l}\text { 3 focus groups with 6 participants each, 76-82 } \\
\text { minutes, audio-taped and transcribed, topics } \\
\text { discussed: learning process (topics, competence }\end{array}$ \\
\hline
\end{tabular}




\begin{tabular}{|l|l|l|l|}
\hline & & $\begin{array}{l}\text { development, methodology), dissemination, concepts } \\
\text { (SD, ESD, sustainable universities) }\end{array}$ \\
\hline $\begin{array}{l}\text { Document } \\
\text { analysis }\end{array}$ & July 2010 & $\begin{array}{l}\text { Final reports of the } 18 \\
\text { participants }\end{array}$ & $\begin{array}{l}\text { Content analysis of the discussion and reflection } \\
\text { chapter in the final reports of the participants, } \\
\text { dimensions of analysis: problems and challenges in } \\
\text { the practical implementation of ESD, added value of } \\
\text { ESD }\end{array}$ \\
\hline
\end{tabular}

The qualitative analysis of the data, oriented to the understanding and reconstruction of the processes of individual competence development, changes in the professional performance, and organisational development, was carried out based on the coding paradigm of the qualitative content analysis developed by Mayring (2000). Qualitative content analysis facilitates a systematic and inter-subjectively verifiable text analysis and thus helped to develop robust findings. Derived from the theoretical background, a first understanding of relevant output processes was used to determine the aspects of the textual material which had to be taken into account. Following this familiarisation with the material, it was worked through and both in vivo and theoretically-derived categories were tentatively deduced. Several feedback loops were incorporated to revise categories, reduce the main categories, and check their reliability (Mayring, 2000).

\section{Findings}

Analysing the data proved notable outcomes on all three levels mentioned earlier as well as between them: (1) individual competence development as a result of the learning process; (2) changes in the professional performance that affected teaching practices; (3) impacts on the organisation as a result of a social learning process. Although the results on each level will be described separately, in practice they were interdependent and reinforcing an aspect that we consider more in detail in the discussion of the findings.

\subsection{Individual competence development}

A strong development of key competencies for sustainability and education for sustainable development is the first and most obvious result of the programme - evident both as self-reported competence development and as observable performance in the final reports and the way each individual`s teaching is restructured around the topic of sustainability.

While it is significant that such competence development in both sustainability as such and in performing education for sustainable development is reported from all participants, this impression should also be justified when analysing the participants' written documents. Two main parts of such key competencies are seen as crucial: (1) different forms of knowledge as cognitive dispositions; (2) abilities and skills which also encompass motivational, non-cognitive dispositions.

Different forms of knowledge are affected, which can be seen as a step-by-step learning process as the participants become familiar with the concept of sustainability. Content-specific knowledge of sustainability which has been acquired by the programme's participants encompasses environmental, social and economic challenges as well as principles and dimensions of the concept of sustainability (such as human wellbeing, intergenerational justice, sustainable use of resources). Process-oriented knowledge is acknowledged as the 
next level of knowledge the participants developed, understanding the links between different dimensions and being able to apply the rather abstract concept to their individual practice. The development of both forms of knowledge is of particular importance for those who are not yet familiar with the concept of sustainability as it is a necessary precondition for introducing the concept into one`s own teaching.

Knowledge about different learning and teaching methods is another key component in the development of cognitive dispositions. The participants' teaching experience to date mainly consists of traditional discipline-oriented teacher-centred teaching styles, and thus collaborative and interdisciplinary learning settings pose great challenges which need a sound knowledge of alternative, innovative methods and approaches (e.g. World Café, future workshop, actor analysis). The participants perceived that knowledge was important for their ability to introduce new learning scenarios: 'I think that all participants have learnt new forms of working in the classroom for being able to work with our students' (discussion group 02).

In addition to the increasing knowledge, the development of certain skills and abilities has been emphasised as very important and closely linked to that knowledge of the participants. The knowledge about different learning and teaching methods has not only been gained in an abstract and theoretical manner, but it also leads to the ability to apply such knowledge in certain situations.

Analysing the process of competence development in more detail shows four key influencing factors: (1) perturbation; (2) raising awareness; (3) opportunities for reflection; (4) learning-by-doing. Perturbation refers to the process of reframing existing knowledge as well as integrating and critically evaluating new knowledge: 'We thought that technological development was always above any other activity, but thanks to this seminar I began to reframe all these ideas' (discussion group 01). Learning and competence development take place here whenever new knowledge does not fit into existing mental models and challenges the participants' world views.

Closely linked is the second influential factor of raising awareness. Dealing with the manifold aspects of sustainability made the participants explore their individual responsibility and how such a reorientation towards sustainability may affect both their personal and professional identity. 'A good personal impact is that it has generated greater awareness and responsibility in every daily action which is performed individually and with the family saving water, we have a place where we can recycle, waste treatment. In this sense it has generated awareness and the idea of replicating more broadly a change of consciousness with students' (discussion group 01). Thus, not only have cognitive processes been triggered, but emotional dispositions have also proved to be of equal importance as the participants had to take into account different levels of urgency as well as opportunities to act.

While the first two factors refer to the initial start of learning processes, the next two proved to be facilitators of the ongoing learning process. The collaborative learning setting with small-group work and explicit reflective phases to consider past and future teaching situations offered the opportunity to reflect on learning progress and to constantly discuss and compare personal views and impressions with other colleagues. This reflection supported deep learning processes and was a major condition of competence development. Finally, the learning process has not only been reflected theoretically, but new learning experiences have also been embedded from the beginning in the participants' practice. The participants highlight the importance of this praxis approach, combining theoretical learning with practical applications in a learning-by-doing approach. Such an approach helped especially to overcome the theory-practice gap as the two processes have not been separated but largely overlapped. 
The following relevant competence areas can be identified in which all of the participants perceived notable improvements - as the data from the focus groups and the questionnaire show - and which also became apparent in the final reports.

The interdisciplinary approach allowed the participants to intensify collaboration and exchange with colleagues from different disciplines. Working together in interdisciplinary teams forced the participants to reflect on each other`s perspectives. 'It was the first time that we dealt interdisciplinarily among faculties and in a very constructive and very positive way with a topic which indeed is common, is global. Never before have we had this opportunity to meet colleagues from different study programmes, different specialties, different views and professional education. [...] It gives us a better perspective, a much clearer picture of what we have to learn. There is a mutual learning process. [...] This is how we should work permanently' (discussion group 02). By experiencing interdisciplinary collaboration, the participants could develop their respective competencies: 'We have prioritised the topic of the interdisciplinary approach, but we've also worked with interdisciplinary methodologies. That has been a very interesting dynamic that has facilitated the development of capacities that maybe at the beginning were not very well defined or not understood' (discussion group 01).

Additionally, the participating teaching staff acknowledged the relevance of transdisciplinarity and its importance for sustainability-related problem-solving: 'Another thing I have assimilated with the course is precisely that part of finding practical solutions, because sustainability needs practical solutions and that, for instance, can be noticed with the inter- and transdisciplinary participation. The issue of transdisciplinarity is a topic that will be a great contribution to the development of the subject. That is to say, as a professor, a member of the university, sometimes you think too much from the academic perspective and you minimise the practices that people do in the field of project reality' (discussion group 01).

Last but not least, the participants had to develop possible solutions to complex problems of unsustainability, which helped to improve their ability to deal with complexity and uncertainty as well as their critical thinking skills, to strengthen their research competencies, and to gain a multi-dimensional perspective.

\subsection{Development of the professional performance of the participants}

The implementation of redesigned modules on topics related to sustainability as part of academics' teaching obligation in the second semester of the programme gave the participants the opportunity to apply their gained knowledge in real-life contexts and to further develop their methodological competencies. Thus, the participants' teaching obligation offered a 'window of opportunity' for a process of learning-by-doing. The teachers experienced how their sustainability-related knowledge and an increased repertoire of teaching and learning methods enriched their learning settings and provided meaningful learning opportunities for their students. 'One aspect that motivated me is the question of methods [...], [before] it was not wide enough to allow the participation of the people. And with that I think it is important that students begin to participate and to generate, and the teacher facilitates those processes [...]. But when you pass the responsibility, hence, the adolescent [...] receiving this responsibility in one way or another tries to get ahead, and that is what we should instil in the students, so that they know how to face challenges' (discussion group 02).

Two main results can be pointed out. The first is that the participants gained first-hand experience of new perspectives on teaching and learning by (1) using innovative methods such as the World Café, the calculation of individual ecological footprints or blended learning; (2) designing the modules as project seminars with increased student-student 
interaction and, in some cases; (3) even facilitating co-operation between students and local communities or other stakeholders: 'Somehow it allowed me to get a better insight into the role as a teacher in the classroom' (discussion group 02). The second result is that a more participative learning culture evolved. The participants felt confident to create much more diverse and participative learning settings than they had been able to before. 'Now we understand things more clearly, and then you can do the job, I think, in a more integrated, holistic way, and I believe that all aspects which have been covered in the course are very important and will help us in carrying out our task; it will give a different perspective on the different methods of work you have been applying, certainly they will allow us to apply them in the classroom' (discussion group 03).

Furthermore, the experience of successfully integrating ESD in their teaching routines influenced the participants' self-confidence, and the positive feedback on their seminars from their students, colleagues or teachers on the academic staff development programme increased their motivation to continue working with the concept of ESD. This feedback, thus, took effect as a driver for the further implementation of ESD. The programme's final workshop helped them to reflect on their experiences in a more structured way and to see more clearly the opportunities and limitation of their teaching approach.

The data also shed light on a more far-reaching impact on the teaching routines of the participants since sustainability as a topic and ESD-related approaches were not only introduced in the specific modules that were developed as part of the programme's workload, but they were also in other modules. As a result of the participants' seminars $(n=18)$ with 30 students each in average participating, some hundreds of students at UTN were exposed to sustainability topics during the academic staff development programme.

In addition, some results of the programme were even transferred to other institutions where some participants also work, e.g. a college or a company. 'In my case, also in meetings in the company - I recently had a meeting and it was about this issue of the environment, thus it was already a focus on what I learned here' (discussion group 02).

\subsection{Organisational impacts of the programme}

In addition to the impact on the individual participants, a number of more far-reaching organisational impacts were observed. The programme contributed to raising awareness of sustainability and creating capacities for implementing ESD. However, the data also reveals influence on other levels of the institution - beyond the area of education - which can be understood as a response of the organisation to the new knowledge, ideas and capacities.

The participants in the academic staff development programme contributed in two different roles to organisational changes. The first was that as individual members of the organisation they facilitated organisational impacts. Three main aspects of this should be mentioned: (1) discussing the programme's objectives with colleagues, which resulted in a broader dissemination of the idea of sustainability in the academic community at the university (2) influencing not only the learning processes of students in the classroom, but also their ideas for the contents and objectives of their thesis projects, and finally (3) experiencing the richness of interdisciplinary work and getting to know colleagues from other disciplines, which not only improved their interdisciplinary skills, but also enhanced collaboration opportunities.

The second role was that as members of the organisation, in official positions or functions they promoted organisational change, for instance, by (1) publishing information related to sustainability in a UTN journal and (2) including sustainability in faculty policy and 
strategies: 'Well, I, for instance, had the opportunity to make the Strategy Plan of the Faculty of Engineering in Applied Sciences, [...], thus, in this [plan] today I put in already the use of ICTs as a cross-cutting issue for all subjects and I put in the cross-cutting issue of sustainability' (discussion group 03).

Given these activities, it becomes evident that the programme not only facilitated the direct, intended formal learning processes in the classroom (for teachers as well as students), but also informal learning in different spheres and levels of the institution. The latter processes also led to new perspectives on the university itself: 'It [the programme] allowed me to understand that the university has to be a centre of debate [...]. Here in the university we have, as teaching staff, the mission to enhance the university as a centre of debate in the community and in this respect we have a lot to do' (discussion group 01).

Facilitated by individual formal and informal learning, the idea of sustainability has spread in the organisation. This dissemination of sustainability can be understood as the impacts of social learning, which can be observed at least in three areas. The first is that conferences and workshops were set up, such as a discussion forum on "Andean Indigenous Cosmovision and Sustainable Development" in June 2010, an international conference on "Quality Management and Sustainable Development in Higher Education" in July 2010, in which not only academic staff and students of the UTN, but also colleagues from other Ecuadorian and Latin-American universities participated, and a conference on "Higher Education for Sustainability" in September 2010, which was again attended by many members of the academic staff together with students of the UTN. The second area is that the diverse sustainability activities created so much interest among members of the university that the academic staff development programme is already being offered a second time with 15 participants. Last but not least, during a two-week seminar for participants in the programme in April 2011 at the Leuphana University of Lüneburg a first draft of a sustainability strategy for the UTN was developed, and this is now being discussed by the academic boards at the UTN.

\section{Discussion}

Discussion of the findings and their implications for the field first requires some limitations of the methodological approach to be acknowledged. The results are 'bounded' to the case study and cannot simply be generalized. Furthermore, the sample is not only small and idiosyncratic, but also consists of academics who voluntarily participated in the programme. Thus, relatively high motivation of all participants and general interest in aspects of sustainability are to be expected. Accordingly, the case study has some unique preconditions that need to be taken into account and will differ in other institutions as well as in follow-up programmes at the same institution. Nevertheless, the qualitative data analysis of the professional development program offers an insight into some of the key processes at UTN that can be considered relevant not only in the specific case setting but also in comparable settings of professional development.

The findings of the study show that the staff development programme has facilitated changes on three levels. First, it fostered personal competence development and provided academics with a broader understanding and more knowledge about sustainability-related issues. Increased reflection on existing values, norms and assumptions enhanced their ability to reflect upon their own practice. These observations are in line with findings in the literature on competence development which point to the importance of reflective processes (Rychen and Salganik, 2003). 
The second aspect is that on the level of professional performance teaching routines were also transformed. The participating teachers were given the opportunity to question their traditional ways of teaching and to experience new and more participative approaches. Here the 'learning-by-doing' approach proved to be crucial as the strong link with teaching and learning practice fostered the participants' commitment and increased their motivation to engage. This confirms the importance of such active learning environments for professional development, as reported e.g. by Garet et al. (2001).

Finally, the academic staff development programme also influenced the general organisational development of the university beyond the teaching approaches alone. The idea of sustainability was disseminated beyond the limits of the programme and it has become a cross-cutting topic in the university. This supports earlier findings by Brodie and Brennan (2009) and Cotton et al. (2009) in that professional development is a relevant factor for integrating sustainability into an institution.

It is important to stress, however, that the three levels are interdependent and reinforce each other. The staff development programme has worked as a promoter of curriculum change towards ESD not only by initiating individual processes of learning and competence development but also by facilitating social (second-order) learning that took place as collective action and reflection, both within the group and in the whole organisation.

In this context, four aspects turned out to be of particular relevance:

- The importance of linking theory and practice: the design of the staff development programme not only facilitated deep reflection on sustainability theory and ESD concepts and methods, but created a setting in which the participating teachers could apply the knowledge gained and hence could also experience the impact on the students' learning processes. By successfully tackling the challenge of overcoming traditional learning and teaching styles, they also increased their selfconfidence and motivation.

- The importance of interdisciplinarity: the programme's participants, who came from different disciplines, worked together and learnt from each other. They experienced the opportunities and limitations of their own discipline as well as other disciplines and thus recognised the importance of interdisciplinary cooperation. This also increased their willingness to work together - across faculties - for sustainable development at their university.

- The importance of informal learning: the learning process of the participating teachers took place not only in the formal learning settings created by the programme but also through informal learning, as they dealt with sustainability issues in different work areas and at home, for instance. Formal and informal learning processes support each other (cf. Barth et al., 2007).

- The link with leadership approaches: the programme's participants were not only asked to implement ESD in their own teaching but were also encouraged to contribute to an organisational change at their university in terms of sustainable development. Leadership encouragement and support in that context are crucial factors for sustaining bottom-up approaches and can be complemented with topdown approaches for further implementation. 


\section{Conclusions}

Higher education for sustainable development aims at facilitating the development of competencies to contribute to a more sustainable future. Thus, sustainable development is not just another topic to be considered in the curriculum, but challenges traditional disciplineoriented and teacher-centred teaching and asks for participatory and competence-oriented approaches in higher education. Academic staff development programmes enable teachers to cope with these challenges, to improve their teaching and learning practice and to boost motivation and confidence in their teaching abilities.

In the light of the case study we introduced we draw two main conclusions, which may inform work at other universities and in the ESD community.

First, education for sustainable development offers the opportunity to introduce new and innovative learning and teaching approaches. Thus it may be both attractive and supportive not only for those interested in the topic of sustainability but also for those who want to improve their teaching skills and learn more about interdisciplinary, problem-based approaches. Such an innovation in teaching and learning also takes place outside of ESD with similar topics addressed in staff development, such as experiential learning (Kolb and Kolb, 2005) or interdisciplinary teaching (Lindman and Tahamont, 2005). However, we see two main advantages in ESD as a framework of such staff development: (1) As a holistic approach it is not only about methods or specific context to be learnt but as well offers a context in which learning takes place, and it links methods and didactical principles with adequate topics and content. Thus, it offers manifold opportunities for reflection and competence development while engaging with complexity and uncertainty. (2) If we consider universities' general social responsibility and their obligation to actively contribute to a sustainable future, framing staff development with ESD may be seen as a "win-win" situation. Dealing with these aspects not only increases teaching competencies, but also leads to better acceptance of the deeper implementation of the concept in the higher education curriculum.

Second, such an academic staff development not only influences the learning and teaching competencies of the staff involved, but also triggers social learning in the organisation. Staff's individual deep learning processes here evolve into social learning and thus contribute to what Hansmann (2010) refers to as "sustainability learning". Furthermore, staff development creates 'windows of opportunity' for organisational change. Even if organisational change towards sustainability has not necessarily to start with staff development, involvement of staff as an important stakeholder group is seen as crucial, and empowering these stakeholders is considered as an critical step for organisational change (Kotter, 1996). Thus, in far-reaching change projects, staff development processes are actively incorporated (Blake and Sterling, 2011; Lozano-Garcia, 2008). Consequently, 'built-in' approaches, understood as deep-rooted implementation of higher education for sustainable development, can be more effectively facilitated by an approach which links staff development and organisational change.

\section{Acknowledgements}

The authors would like to thank their colleagues, both at the Universidad Técnica del Norte (UTN), Ecuador, and at the Leuphana University of Lüneburg, Germany, whose support and strong commitment to the ambitious project made this programme possible. Special thanks go to Dr. Patricia Aguirre (Institute for Postgraduate Studies, UTN) for the 
close collaboration during the development and implementation of the programme as well as the data collection. We also acknowledge the financial support from the German Academic Exchange Service (DAAD) as the funding agency of the project 'Teaching and Learning Sustainability'. The writing of the article was supported for the corresponding author by a fellowship in the Postdoc Programme of the German Academic Exchange Service (DAAD). We also gratefully recognise all of the individuals who participated in the academic staff development programme and the process of data collection. Finally, the authors thank the three anonymous reviewers for their constructive comments on an earlier draft of the article.

\section{References}

Adomßent, M., Michelsen, G., 2006. German Academia heading for sustainability? Reflections on policy and practice in teaching, research and institutional innovations. Environmental Education Research 12, 85-99.

Argyris, C., 2009. On organizational learning, 2. ed., [reprinted]. Blackwell, Malden, Mass.

Argyris, C., Schön, D.A., 1996. Organizational learning II. Theory, Method, and Practice, Reprinted with corr. Addison-Wesley Pub, Reading, Mass.

Barnett, R., Parry, G., Coate, K., 2001. Conceptualising Curriculum Change. Teaching in Higher Education 6, 435-449.

Barth, M., 2011. Den konstruktiven Umgang mit den Herausforderungen unserer Zeit erlernen: Bildung für nachhaltige Entwicklung als erziehungswissenschaftliche Aufgabe. [How to Deal Constructively with the Challenges of our Times - Education for Sustainable Development as an Educational Objective]. SWS Rundschau 51, 275-291.

Barth, M., Godemann, J., Rieckmann, M., Stoltenberg, U., 2007. Developing Key Competencies for Sustainable Development in Higher Education. International Journal of Sustainability in Higher Education, 416-430.

Barth, M., Timm, J.-M., 2011. Higher Education for Sustainable Development. Students`́ Perspectives on an Innovative Approach to Educational Change. Journal of Social Science 7, 13-23.

Bassey, M., 1999. Case study research in educational settings, Reprinted. Open University Press, Buckingham.

Blake, J., Sterling, S., 2011. Tensions and transitions: effecting change towards sustainability at a mainstream university through staff living and learning at an alternative, civil society college. Environmental Education Research 17, 125-144.

Bremer, M.H., López-Franco, R., 2006. Sustainable development: ten years of experience at ITESM's graduate level. Journal of Cleaner Production 14, 952-957.

Brodie, C.A., Brennan, D., 2006. Environmental sustainability programs in higher education: Policies, practices and curriculum strategies. University of the Pacific, Stockton.

Ceulemans, K., De Prins, M., 2010. Teacher's manual and method for SD integration in curricula. Journal of Cleaner Production 18, 645-651.

Clark, W.C., Dickson, N.M., 2003. Sustainability science: The emerging research program. Proceedings of the National Academy of Sciences of the United States of America 100, 8059-8061.

Corcoran, P.B., Walker, K.E., Wals, A.E.J., 2004. Case studies, make-your-case studies, and case stories. a critique of case-study methodology in sustainability in higher education. Environmental Education Research, 7-21. 1.

Cortese, A.D., 2003. The Critical Role of Higher Education in Creating a Sustainable Future. Planning for Higher Education 31, 15-22.

Cotton, D., Bailey, I., Warren, M., Bissell, S., 2009. Revolutions and second-best solutions: education for sustainable development in higher education. Studies In Higher Education 34, 719-733.

Cramer, J., Loeber, A., 2007. Learning about corporate social responsibility from a sustainable development perspective:. A Dutch experiment, in: Wals, A.E.J. (Ed.), Social learning towards a sustainable world. Principles, perspectives, and praxis. Wageningen Academic Publishers, Wageningen, pp. 265-278.

Creswell, J.W., 1998. Qualitative inquiry and research design. Choosing among five traditions. Sage Publications, Thousand Oaks.

Denzin, N.K., Lincoln, Y.S., 1998. Introduction, in: Denzin, N.K., Lincoln, Y.S. (Eds.), Collecting and interpreting qualitative materials, Thousand Oaks, pp. 1-34.

Drake, S.M., 1998. Creating integrated curriculum. Proven ways to increase student learning. Thousand Oaks.

Dressel, P.L., Marcus, D., 1982. On teaching and learning in college. reemphasizing the roles of learners and the disciplines. Jossey-Bass, San Francisco. 
Eckel, P.D., Kezar, A.J., 2003. Key Strategies for Making New Institutional Sense. Ingredients to Higher Education Transformation. Higher Education Policy 16, 39-53.

Ellsworth, J.B., 2000. Surviving change. A survey of educational change models. Clearinghouse on Information \& Technology Syracuse University, Syracuse.

Epstein, A.W., Bras, R.L., Bowring, S.A., 2009. Building a freshman-year foundation for sustainability studies: Terrascope, a case study. Sustainability Science 4, 37-43.

Fadeeva, Z. , Mochizuki, Y., 2010. Higher education for today and tomorrow: university appraisal for diversity, innovation and change towards sustainable development. Sustainability Science 5, 249-256.

Ferrer-Balas, D., Buckland, H., Mingo, M. de, 2009. Explorations on the University's role in society for sustainable development through a systems transition approach. Case-study of the Technical University of Catalonia (UPC). Journal of Cleaner Production 17, 1075-1085.

Fien, J., 2002. Advancing Sustainability in Higher Education. Issues and Opportunities for Research. Higher Education Policy 15, 143-152.

Flint, R.W., McCarter, W., Bonniwell, T., 2000. Interdisciplinary education in sustainability: links in secondary and higher education. The Northampton Legacy Program. International Journal of Sustainability in Higher Education 1, 191-202.

Fullan, M., 2003. Change Forces with a Vengeance. Routledge Falmer, London.

Garet, M.S., Porter, A.C., Desimone, L., Birman, B.F., Yoon, K.S., 2001. What Makes Professional Development Effective? Results From a National Sample of Teachers. American Educational Research Journal 38, 915-945.

Gough, S., Scott, W., 2007. Higher education and sustainable development. Paradox and possibility. Routledge Falmer, London.

Hansmann, R., 2010. "Sustainability Learning”: An Introduction to the Concept and Its Motivational Aspects. Sustainability 2, 2873-2897.

Hegarty, K., 2008. Shaping the self to sustain the other. mapping impacts of academic identity in education for sustainability. Env. Educ. Res 14, 681-692.

Hoare, A., Cornell, S., Bertram, C., Gallagher, K., Heslop, S., Lieven, N., MacLeod, C., Morgan, J., Pickering, A., Wells, S., Willmore, C., 2008. Teaching against the grain. multi-disciplinary teamwork effectively delivers a successful undergraduate unit in sustainable development. Environmental Education Research 14, 469-481.

Holmberg, J., Svanström, M., Peet, D.-J., Mulder, K., Ferrer-Balas, D., Segalàs, J., 2008. Embedding sustainability in higher education through interaction with lecturers: Case studies from three European technical universities. European Journal of Engineering Education 33, 271- 282.

Huisingh, D., Mebratu, D., 2000. “Educating the educators” as a strategy for enhancing education on cleaner production. Journal of Cleaner Production 8, 439-442.

Ison, R.L., Russell, D.B., 2000. Agricultural extension and rural development. Breaking out of traditions; a second-order systems perspective. Cambridge University Press, Cambridge.

Jones, P., Trier, C.J., Richards, J.P., 2008. Embedding Education for Sustainable Development in higher education: A case study examining common challenges and opportunities for undergraduate programmes. International Journal of Educational Research 47, 341-350.

Juárez-Nájera, M., Dieleman, H., Turpin-Marion, S., 2006. Sustainability in Mexican Higher Education. towards a new academic and professional culture. Journal of Cleaner Production 14, 1028-1038.

Kates, R.W., Clark, W.C., Corell, R., Hall, J.M., Jaeger, C.C., James, L.I., McCarthy, J.J., Schellnhuber, H.J., Bolin, B., Dickson, N.M., Faucheux, S., Gallopin, G.C., Grübler, A., Huntley, B., Jäger, J., Jodha, N.S., Kasperson, R.E., Mabogunje, A., Matson, P., Mooney, H., Moore, B., O’Riordan, T., Svedin, U., 2001. Sustainability Science. Policy forum: Environment and Development. Science 292, 641-642.

Keen, M., Brown, V.A., Dyball, R., 2005. Social Learning in Environmental Management. Towards a Sustainable Future. Earthscan, London.

Kolb, A.Y., Kolb, D.A., 2005. Learning Styles and Learning Spaces: Enhancing Experiential Learning in Higher Education. Academy of Management Learning \& Education 4, 193-212.

Kotter, J.P., 1996. Leading change. Harvard Business School Press, Boston, Mass.

La Harpe, B. de, Thomas, I., 2009. Curriculum Change in Universities. Conditions that Facilitate Education for Sustainable Development. Journal of Education for Sustainable Development 3, 75-85.

Leal Filho, W., 2009. Sustainability at Universities: Opportunities, Challenges and Trends, in: Leal Filho, W. (Ed.), Sustainability at Universities - Opportunities, Challenges and Trends. Peter Lang, Frankfurt/Main, Berlin, Bern, Brussels, New York, Oxford, Wien, pp. 313-319.

Lidgren, A., Rodhe Hakan, Huisingh Don, 2006. A systemic approach to incorporate sustainability into university courses and curricula. Journal of Cleaner Production 14, 797-809. 
Lindquist, J., 1974. Political Linkage. The Academic-Innovation Process. The Journal of Higher Education 45, 323-343.

Lindman, J., Tahamont, M., 2005. Transforming Selves, Transforming Courses: Faculty and Staff Development and the Construction of Interdisciplinary Diversity Courses. Innovative Higher Education 30, 289-304.

Lozano, R., 2006. Incorporation and institutionalization of SD into universities. breaking through barriers to change. Journal of Cleaner Production 14, 787-796.

Lozano, R., 2010. Diffusion of sustainable development in universities' curricula. an empirical example from Cardiff University. Journal of Cleaner Production 18, 637-644.

Lozano-García, F.J., Gándara, G., Perrni, O., Manzano, M., Hernández, D.E., Huisingh, D., 2008. Capacity building: a course on sustainable development to educate the educators. International Journal of Sustainability in Higher Education 9, 257-281.

Lozano-García, F.J., Huisingh, D., Delgado-Fabián, M., 2009. An interconnected approach to incorporate sustainable development at Tecnológico de Monterrey. International Journal of Sustainability in Higher Education 10, 318-333.

Lund-Thomsen, P., 2007. Corporate social responsibility:. Towards a new dialogue?, in: Wals, A.E.J. (Ed.), Social learning towards a sustainable world. Principles, perspectives, and praxis. Wageningen Academic Publishers, Wageningen, pp. 297-312.

Martens, P., 2006. Sustainability: science or fiction? Sustainability: Science, Practice \& Policy 2, 36-41.

Mayring, P., 2000. Qualitative Content Analysis. Forum: Qualitative Social Research 1, Art. 20.

Mc Millin, J., Dyball, R., 2009. Developing a Whole-of-University Approach to Educating for Sustainability. Linking Curriculum, Research and Sustainable Campus Operations. Journal of Education for Sustainable Development 3, 55-64.

Merriam, S.B., 1998. Qualitative Research and Case Study Applications in Education, San Francisco.

Michelsen, G., Rieckmann, M., 2008. International Master's Programme in Sustainable Development and Management. Volume 2: Introduction to Sustainable Development. VAS-Verlag für Akademische Schriften, Bad Homburg.

Morgan, D.L., 1997. Focus groups as qualitative research. 2. Edition, Thousand Oaks.

Murray, P.E., Murray, S.A., 2007. Promoting sustainability values within career-oriented degree programmes. A case study analysis. International Journal of Sustainability in Higher Education 8, 285-300.

Perdan, S., Azapagic, A., Clift, R., 2000. Teaching sustainable development to engineering students. International Journal of Sustainability in Higher Education 1, 267-279.

Roberts, C., Roberts, J., 2008. Starting with the staff. How swapshops can develop ESD and empower practitioners. Environmental Education Research 14, 423-434.

Rockstrom, J., Steffen, W., Noone, K., Persson, A., Chapin, F.S., Lambin, E.F., Lenton, T.M., Scheffer, M., Folke, C., Schellnhuber, H.J., Nykvist, B., Wit, C.A. de, Hughes, T., van der Leeuw, S., Rodhe, H., Sorlin, S., Snyder, P.K., Costanza, R., Svedin, U., Falkenmark, M., Karlberg, L., Corell, R.W., Fabry, V.J., Hansen, J., Walker, B., Liverman, D., Richardson, K., Crutzen, P., Foley, J.A., 2009. A safe operating space for humanity. Nature 461, 472-475.

Rychen, D.S., Salganik, L.H., 2003. A holistic model of competence, in: Rychen, D.S., Salganik, L.H. (Eds.), Key competencies for a successful life and well-functioning society. Hogrefe \& Huber Publishers, Cambridge, pp. 41-62.

Scott, W., Gough, S., 2006. Universities and Sustainable Development in a Liberal Democracy. A Reflection on the Necessity for Barriers to Change, in: Holmberg, J., Samuelsson, B.E. (Eds.), Drivers and Barriers for Implementing Sustainable Development in Higher Education, Paris, pp. 88-95.

Senge, P.M., 2006. The fifth discipline. The art and practice of the learning organization. Currency Doubleday, New York.

Siebenhüner, B., Arnold, M., 2007. Organizational learning to manage sustainable development. Bus. Strat. Env 16, 339-353.

Stark, J.S., Lattuca, L.R., 1997. Shaping the college curriculum. Academic plans in action. Allyn and Bacon, Boston.

Sterling, S., 2004. Higher Education, Sustainability, and the Role of Systemic Learning, in: Blaze Corcoran, P., Wals, A.E.J. (Eds.), Higher Education and the Challenge of Sustainability. Problematics, Promise, and Practice. Springer Netherlands, Dordrecht, pp. 47-70.

Sterling, S., 2007. Riding the storm: towards a connective cultural consciousness, in: Wals, A.E.J. (Ed.), Social learning towards a sustainable world. Principles, perspectives, and praxis. Wageningen Academic Publishers, Wageningen, pp. 63-82.

Sterling, S., Thomas, I., 2006. Education for sustainability: the role of capabilities in guiding university curricula. International Journal of Innovation and Sustainable Development 1, 349-370. 
Thomas, I., 2004. Sustainability in tertiary curricula: what is stopping it happening? International Journal of Sustainability in Higher Education 5, 33-47.

Tilbury, D., 2004. Environmental Education for Sustainability: A Force for Change in Higher Education, in: Blaze Corcoran, P., Wals, A.E.J. (Eds.), Higher Education and the Challenge of Sustainability. Problematics, Promise, and Practice. Springer Netherlands, Dordrecht, pp. 97-112.

Toombs, W., Tierney, W., 1991. Meeting the mandate. Renewing the college and department curriculum. School of Education and Human Development George Washington University, Washington, D.C.

Trinkaus, J.W., Booke, A.L., 1980. The curriculum change process: Participants, Strategies, and Tactics. Research in Higher Education 13, 307-319.

United Nations Educational Scientific and Cultural Organization (UNESCO), 2004. United Nations Decade of Education for Sustainable Development 2005-2014. Draft International Implementation Scheme, Paris.

Uwasu, M., Yabar, H., Hara, K., Shimoda, Y., Saijo, T., 2009. Educational initiative of Osaka University in sustainability science: mobilizing science and technology towards sustainability. Sustainability Science 4, 45-53.

Vann, J., Pacheco, P., Motloch, J., 2006. Cross-cultural education for sustainability: development of an introduction to sustainability course. Journal of Cleaner Production.

Vare, P., Scott, W., 2007. Learning for a Change: Exploring the Relationship Between Education and Sustainable Development. Journal of Education for Sustainable Development 1, 191-198.

Wals, A., 2009. A Mid-DESD Review: Key Findings and Ways Forward. Journal of Education for Sustainable Development, 195-204.

Wals, A.E.J., van der Leij, T., 2007. Introduction, in: Wals, A.E.J. (Ed.), Social learning towards a sustainable world. Principles, perspectives, and praxis. Wageningen Academic Publishers, Wageningen, pp. 17-32.

Wright, T.S.A., Pullen, S., 2007. Examining the Literature: A Bibliometric Study of ESD Journal Articles in the Education Resources Information Center Database. Journal of Education for Sustainable Development 1, 77-90.

Yin, R.K., 1989. Case study research. Design and methods, Sage Publications, Beverly Hills.

\footnotetext{
${ }^{1}$ Formal accreditation was approved by the Ecuadorian National Council for Higher Education, a crucial aspect for interested participants to commit themselves to such a high workload.

${ }^{2}$ Moodle (http://www.moodle.org) is an open-source learning management system.
} 